\title{
Prevalence of Avian Influenza H5N6 in Birds: A Systematic Review and Meta-analysis of Other Viral Zoonosis
}

\author{
D. Katterine Bonilla-Aldana ${ }^{1,2}$, Yeimer Holguin-Rivera ${ }^{2}$, Isabella Cortes-Bonilla ${ }^{2}$, María C. Cardona-Trujillo ${ }^{2}$, \\ Alejandra García-Barco ${ }^{2}$, Hugo A. Bedoya-Arias ${ }^{2}$, Leidy Jhoana Patiño-Cadavid ${ }^{2}$, Mateo Aguirre-Florez ${ }^{2}$, Graciela J. \\ Balbin-Ramon ${ }^{3,4}$, Delcy C. Erazo-Arana ${ }^{2}$, Lysien I. Zambrano ${ }^{5}$, Luis Perez-Garcia ${ }^{6}$, Alfonso J. Rodriguez-Morales ${ }^{2,3,7 *}$, \\ and Alberto Paniz-Mondolfi ${ }^{6,8,9,10}$

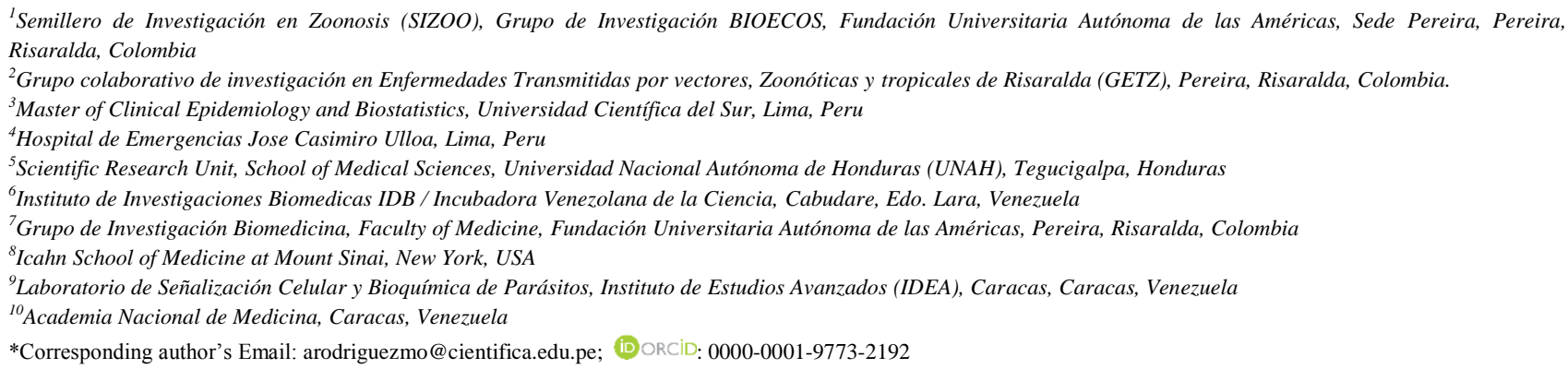

\begin{abstract}
Avian influenza viruses (AIV) are zoonotic pathogens that can potentially affect humans and potentially be epidemic in a region. Birds (such as poultry and wild birds) serve as potential reservoirs for these viruses, highlighting the importance of determining AIV prevalence in the avian population. No systematic reviews have been published on this issue in the world so far. The present systematic literature review following the PRISMA standard, with metaanalysis, used three databases to globally assess the Influenza H5N6 infection in birds (including poultry and wild birds). A model of random-effects meta-analysis was performed to calculate the pooled prevalence and $95 \%$ Confidence Interval $(95 \%$ CI) for the prevalence of Influenza H5N6 infection in birds. A total number of 14,605 articles published from 2015 to 2020 were retrieved. After screening the abstract/title, 37 articles were selected for full-text assessment, and 15 were included for qualitative and quantitative analyses. Of the total number of birds $(\mathrm{n}=$ 13,416 birds), the pool prevalence by RT-PCR was 3.5\% (95\% CI: $2.8-4.3 \%$ ). From the total, 39.67\% of the birds assessed were ducks (family Anatidae), in which pool prevalence was 7.7\% (95\% CI: 4.4-11.0). In chickens (Gallus gallus domesticus), the pool prevalence was 3.3\% (95\% CI 1.9-4.8). Vietnam was the country with the highest pool prevalence; $7.9 \%$ (95\% CI 4.0-11.7\%). Bangladesh was the country with the lowest pool prevalence of $0.4 \%(95 \%$ CI $0.2-0.7 \%$ ). A considerable proportion of infected birds tested positive highlighted the relevance of individual animals as reservoirs of H5N6. Ducks and chickens were found to be positive by RT-PCR in over 3\% of the cases. These data suggest their relevance in maintaining zoonotic transmission and their potential implications for epidemics and even pandemics in the near future.
\end{abstract}

Keywords: H5N6, Influenza, Meta-Analysis, Molecular diagnosis, RT-PCR, Systematic Review

\section{INTRODUCTION}

Avian influenza viruses (AIV) belong to the Alphainfluenzavirus genus in the Orthomyxoviridae family (Lefkowitz et al., 2018). They can be classified into Low-Pathogenic Avian Influenza Viruses (LPAIVs) with water birds as primary host reservoirs and Highly Pathogenic Avian Influenza Viruses (HPAIVs) with poultry as the main host reservoirs (Dhingra et al., 2018). These viruses can be brought long distances by aquatic birds, transmitted at chicken farms, and infect naive poultry (Bi et al., 2016). Highly Pathogenic Avian Influenza Viruses (HPAIVs) remain an underlying threat to global health and the economy. Some of these viruses carry potential pandemic risks (Swayne et al., 2017; Shin et al., 2020; Shittu et al., 2020).

H5N6, an AIV subtype, was first isolated from mallards in 1975 (Garcia et al., 1997). This virus has continuously evolved and reasserted to generate novel HPAIVs that have led to several epidemics incidents; in 2014, Laos and Vietnam reported an Influenza H5N6 outbreak that killed hundreds of birds (Shen et al., 2015), possibly imported from live poultry from China (Wong et al., 2015). In the same year, China reported the first fatal case of Influenza H5N6 
among its people (Pan et al., 2016). To date, 24 confirmed cases of human infection with influenza A (H5N6) virus have been reported to the World Health Organization (WHO) from China since 2014 resulting in seven deaths (World Health Organization, 2020).

Since birds play a pivotal role as natural hosts and reservoirs for this virus, a clearer understanding of bird-tohuman transmission dynamics across wild, urban, and suburban settings is essential. Thus, a systematic review and metaanalysis of AIV were set to synthesize previously published data that assessed H1N6 infection in birds using the reversetranscriptase polymerase chain reaction (RT-PCR). Then, this systematic review's main objective was to summarize the frequency of Influenza H5N6 infection in birds reported in currently available observational studies. Also, it was to examine the differences among the pool prevalence of H5N6 infections by animal, sample, and year.

\section{METHODS}

\section{Protocol}

The present systematic review followed the PRISMA statement's recommendations (Preferred Reporting Items for Systematic Review and Meta-Analysis, Moher et al., 2009).

\section{Eligibility criteria}

Published peer-reviewed articles that reported H5N6 infection in birds with serological or molecular confirmation by RT-PCR were included. The articles' language was not limited to English, and the publications were considered from January 1, 2002, to April 1, 2020, when the search ended. The exclusion criteria included review articles, opinion articles, correspondence articles or letters not presenting original data, and reports with incomplete information.

\section{Information sources and search strategy}

Medline/PubMed, Scopus, and Web of Sciences were used in the present systematic review. The search procedure was accomplished using the following terms "influenza", "avian influenza", "H5N6", "birds", and "influenza A". These words were used in combination while searching. Searching for this review ended on the date April 1, 2020, and a group of four different researchers evaluated the results yielded independently.

\section{Study selection}

The initial search strategy was first screened by title and abstract, as used in other systematic reviews (Rodriguez-Morales et al., 2020). The full text of relevant articles was examined for inclusion and exclusion criteria (Figure 1). When an article reported the same information from the same patient, both reports' information was combined to obtain complementary data, counted as a single case. Observational studies that reported the frequency of H5N6 infection in birds were included for quantitative synthesis (metanalysis).

\section{Data collection and data items}

Data extraction questionnaires, including information on the type of articles, publishing institution, country, year, and date of publication, as well as the number of infected animals assessed by RT-PCR, were filled independently by four researchers. An additional researcher checked the article list and data extractions to ensure no duplicate articles or duplicate information of the same study and resolved discrepancies about study inclusion. Regarding countries, the review found studies from China, Bangladesh, Myanmar, and Vietnam.

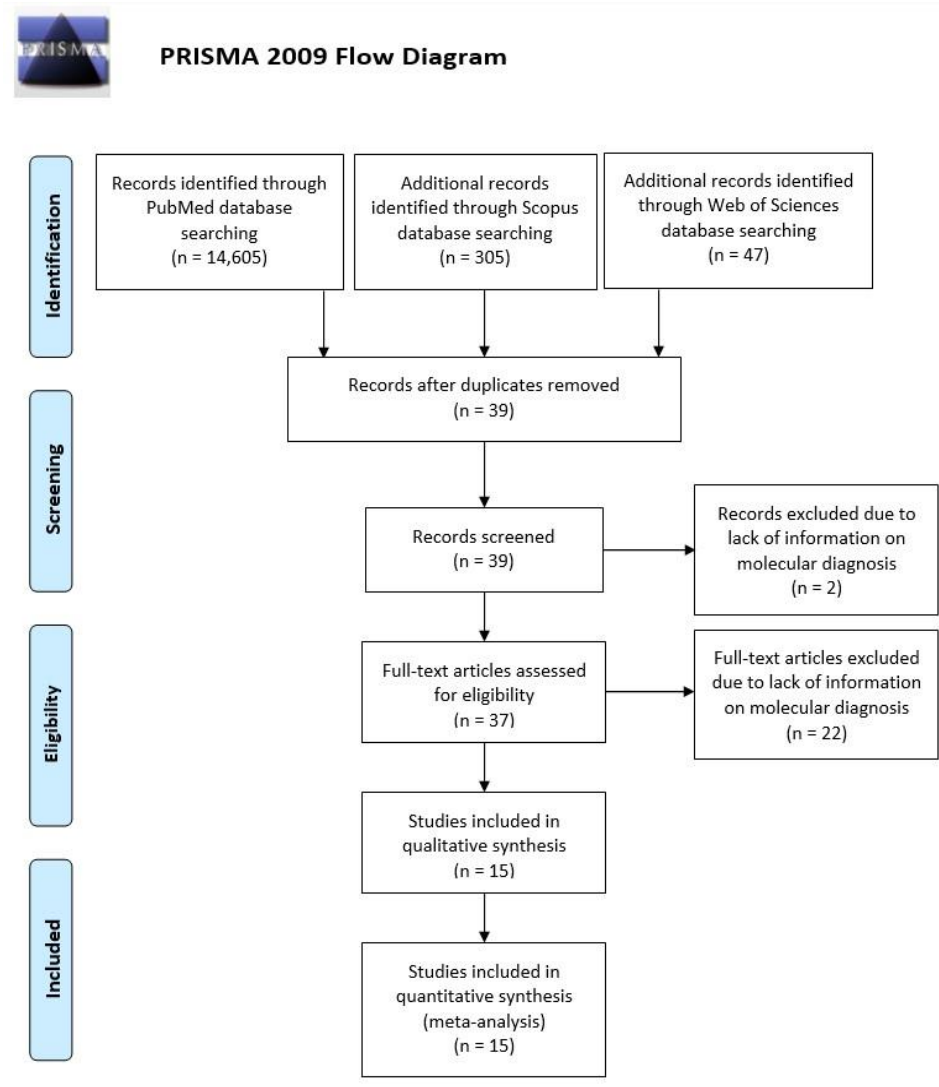

Figure 1. Study selection and characteristics of the articles included and considered for the qualitative and quantitative synthesis of data 


\section{Assessment of methodological quality and risk of bias}

To evaluate the quality of cross-sectional studies (AXIS), the critical appraisal tool from the Quality Appraisal of Case Series Studies Checklist of the Institute of Health Economics (IHE) was used (IHE, 2014; Downes et al., 2016). Publication bias was measured using a funnel plot. A model of random-effects was used to calculate the pooled prevalence and 95\% CI, given variable degrees of data heterogeneity. The intrinsic heterogeneity in any systematic review of studies from published literature should be considered, then, also Egger's test was applied.

\section{Statistical approach}

Unit discordance for variables was resolved by converting all units into a standard measurement. The baseline data were analyzed using Stata version 14.0, licensed by Universidad Tecnológica de Pereira.

The meta-analysis was performed using Stata, Open Meta (Analyst) Software, and Comprehensive Meta-Analysis ve.3.3® licensed by Universidad Tecnológica de Pereira, Colombia. Pooled prevalences and their 95\% confidence intervals (95\% CIs) were used to summarize the weighted effect size for each study grouping variable using the binary random-effects model, considering the sample size of individual studies. For median ages, a continuous random-effect model was applied (DerSimonian-Laird procedure). A model of random-effects meta-analysis presumes that the effects being estimated in the different studies are not identical but follow some distribution. For random-effects analyses, the pooled estimate and $95 \%$ CIs refer to the center of the pooled prevalence distribution but do not describe the width of the distribution. Often the pooled estimate and its $95 \% \mathrm{CI}$ are quoted in isolation as an alternative estimate of the quantity evaluated in a fixed-effect meta-analysis, which is inappropriate. The 95\% CI from a random-effects meta-analysis describes uncertainty in the mean of systematically different prevalence in different studies.

Measures of heterogeneity, including Cochran's Q statistic, the $\mathrm{I}^{2}$ index, and the tau-squared test, were estimated and reported, as elsewhere (Rodriguez-Morales et al., 2020). The subgroup analyses (sub-meta-analyses) were performed by diagnostic technique, animals, and countries.

\section{RESULTS}

\section{Study selection and characteristics}

A total of 14,605 articles were retrieved using the mentioned search strategy; 37 articles were selected for full-text assessment after screening by abstract and title. The rest were excluded as not containing relevant information and data for the systematic review. Twenty-two articles were excluded due to lack of information on molecular diagnosis, and 15 articles were finally included for the final qualitative and quantitative meta-analysis (Figure 1). Table 1 presents the main characteristics of the included studies.

The present review included 15 cross-sectional prevalence studies published from January 1, 2015, to April 1, 2020, which most of them were from China (81\%), Vietnam (9\%), Myanmar (9\%), and Bangladesh (3\%, tables 1 and 2), with a total of 13,416 birds assessed by RT-PCR. Three main variables (bird grouping, countries, and years) for the meta-analyses were analyzed (Table 2). Publication bias was reviewed with a funnel plot for the standard error by logit event, with no evidence of bias (Figure 2). Additionally, the Egger test suggested no substantial evidence of publication bias $(\mathrm{p}=0.568)$.

\section{Individual study characteristics}

The mean number of included animals for RT-PCR per study was 407 , with positive rates ranging from 0 to $53.8 \%$ (Tables 1-2).

\section{Main findings}

The RT-PCR pool prevalence for H5N6 was 3.5\% (95\% CI: 2.8-4.3\%, Figure 3), 39.67\% corresponded to ducks, with a pool prevalence of $7.7 \%$ (95\% CI: 4.4-11.0, Figure 4), 35.63\% corresponded to chickens, with a pool prevalence of $3.3 \%$ (95\% CI: $1.9-4.8$ ), and $19.15 \%$ of them were non-specified poultry birds, with the pool prevalence of $5.1 \%(95 \%$ CI: $0.0-14.8 \%$, Table 2 and Figure 4).

Among the countries with the highest prevalence, Vietnam and China showed no significant differences. Vietnam with 538 animals and China with 4212 animals yielded a pool prevalence of $7.9 \%$ (95\%CI: 4.0-11.7\%) and $6.0 \%$ (95\% CI: 4.3-7.8\%). Myanmar and Bangladesh yielded a prevalence of $1.3 \%$ and $0.4 \%$, respectively (Figure 5 and Table 2). The year 2018 had the highest prevalence (21.2\%), followed by $2019(8.3 \%)$ and 2020 (5.0\%, Figure 6 and Table 2). 


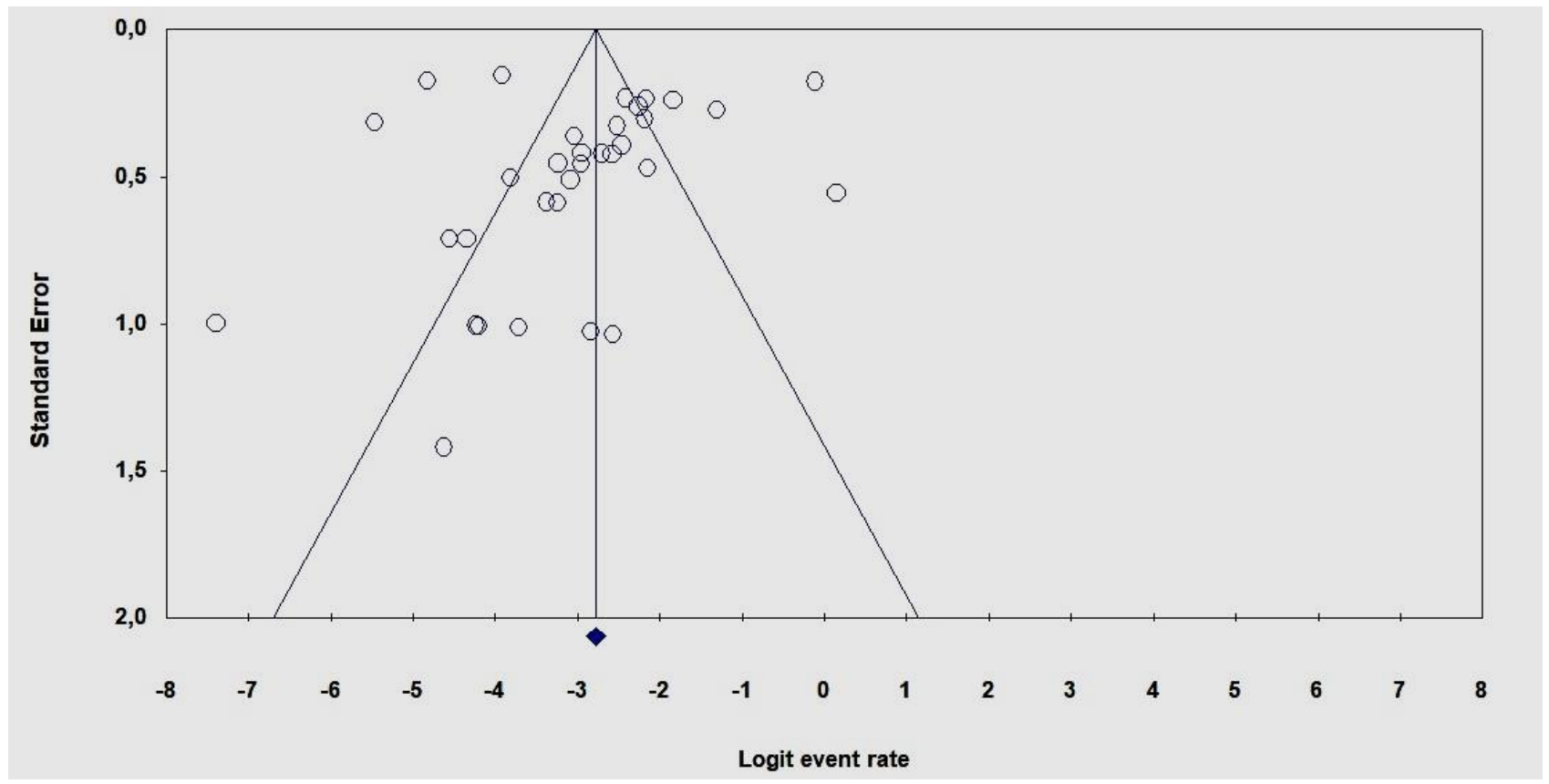

Figure 2. Funnel-plot for the standard error by logit event rate to assess the publication bias

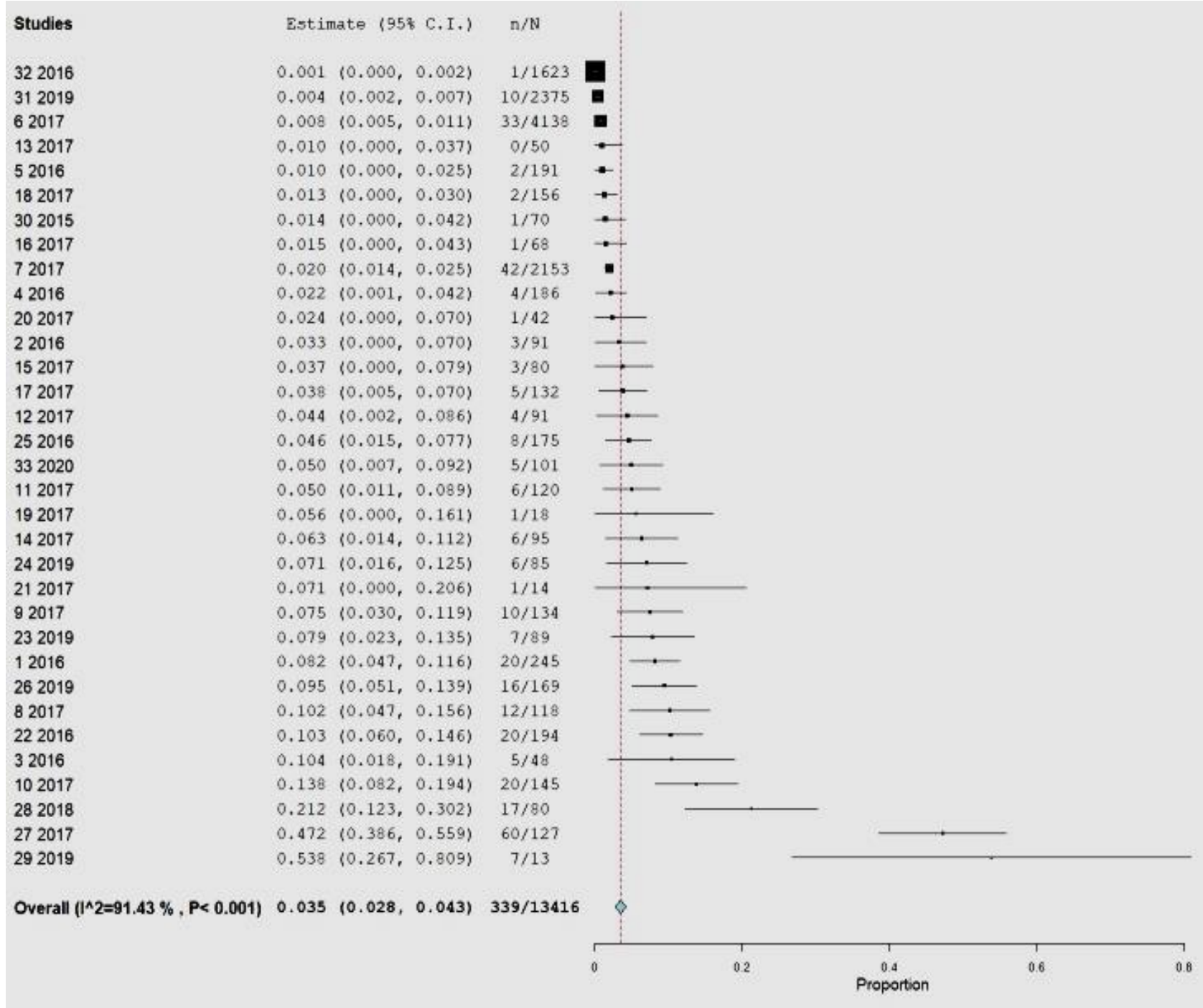

Figure 3. Forrest plot of the pooled prevalence meta-analysis of H5N6 infection in birds 


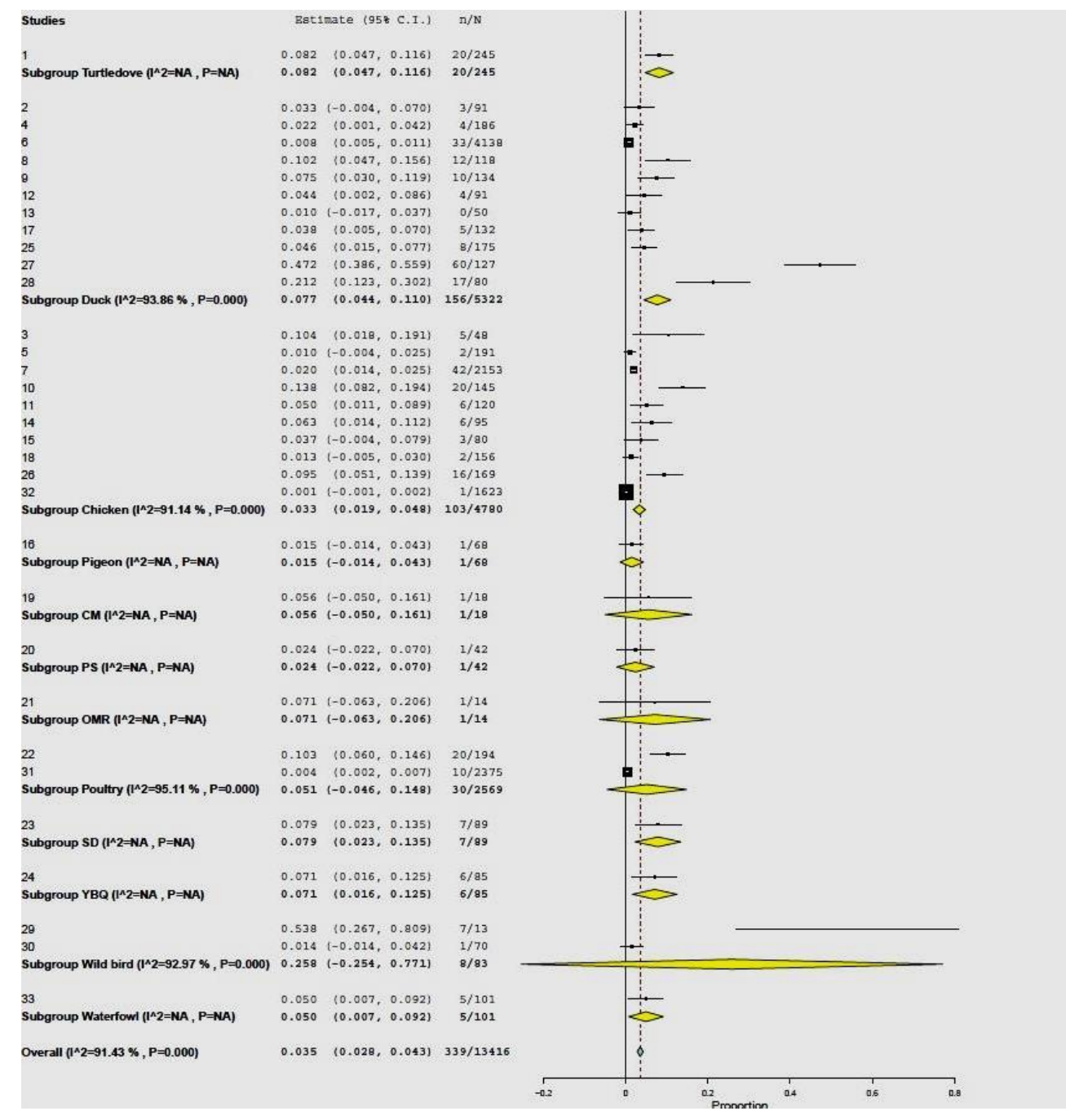

Figure 4. Forrest plot of the pooled prevalence meta-analysis of H5N6 infection in birds, by families or bird groups

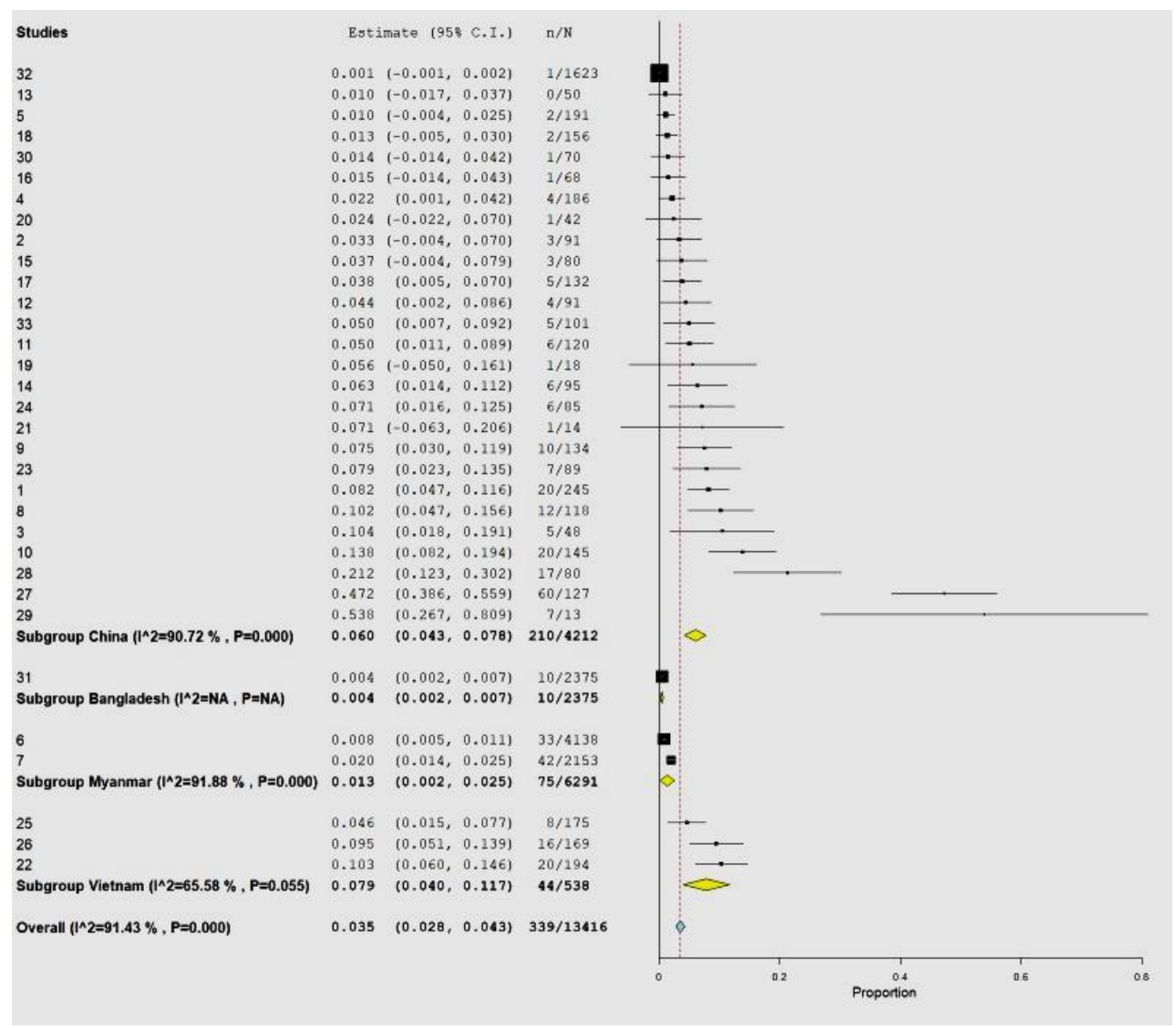

Figure 5. Forrest plot of the pooled prevalence meta-analysis of H5N6 infection in birds in terms of countries

To cite this paper: Bonilla-Aldana DK, Holguin-Rivera Y, Cortes-Bonilla I, Cardona-Trujillo M.C., García-Barco A, Bedoya-Arias HA, Patiño-Cadavid LJ, Aguirre-Florez M, Balbin-Ramon GJ, Erazo-Arana DC, Zambrano LI, Perez-Garcia L, Rodriguez-Morales AJ, and Paniz-Mondolfi A (2021). Prevalence of Avian Influenza H5N6 in Birds: A Systematic Review and Meta-analysis of Other Viral Zoonosis. World Vet. J., 11 (2): 146-156. 


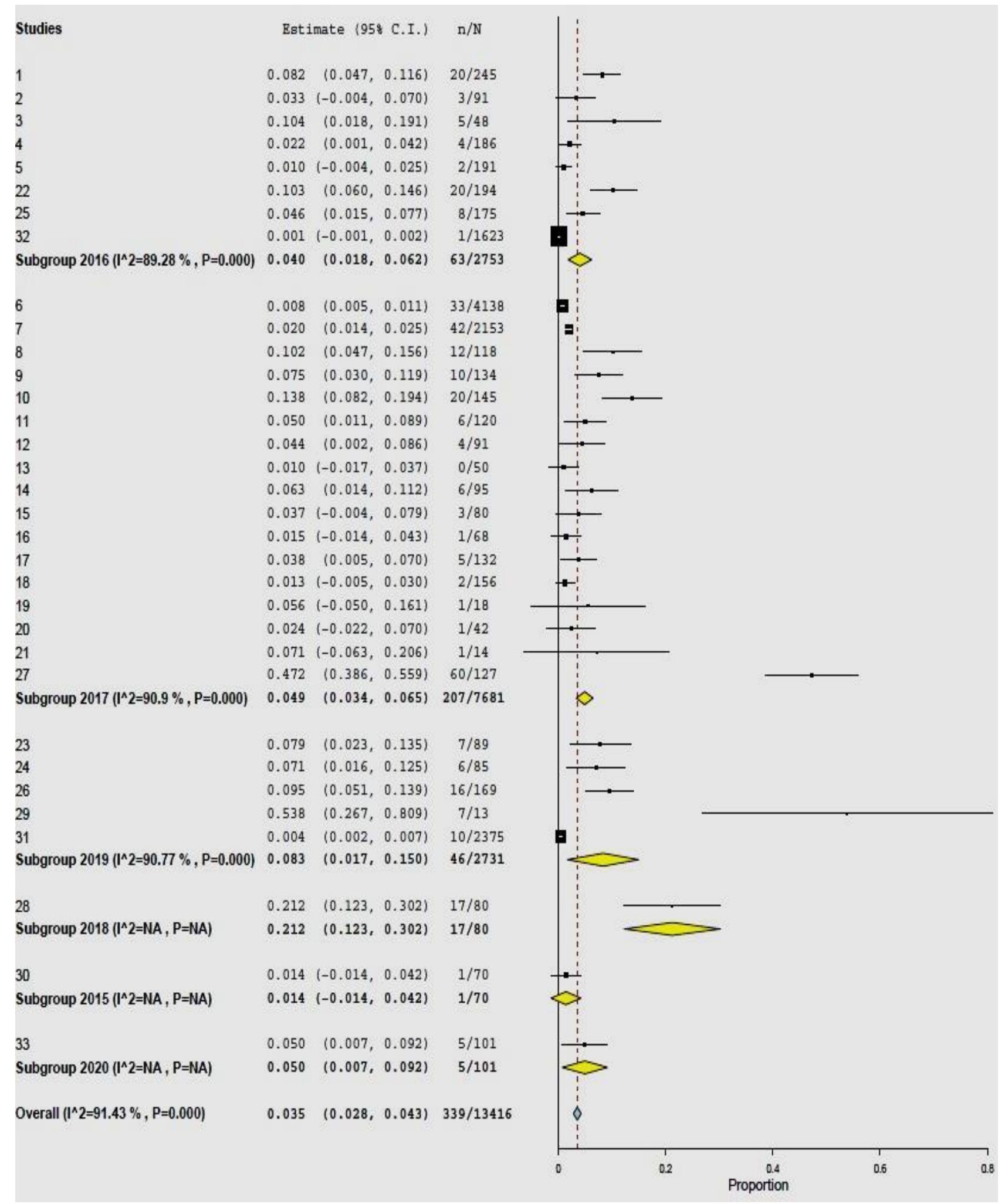

Figure 6. Forrest plot of the pooled prevalence meta-analysis of H5N6 infection in birds regarding years 
Table 1. Characteristics of the included studies on avian Influenza H5N1 in birds

\begin{tabular}{|c|c|c|c|c|c|c|c|c|c|c|}
\hline Title of the study & $\begin{array}{l}\text { Publication } \\
\quad \text { Year }\end{array}$ & $\begin{array}{l}\text { Study } \\
\text { Years }\end{array}$ & Country & Place & Birds Assessed & Sample & $\mathbf{N}$ & $\begin{array}{c}\mathbf{n} \\
(+)\end{array}$ & $\begin{array}{l}\text { Positive } \\
(\%)\end{array}$ & Reference \\
\hline \multirow{5}{*}{$\begin{array}{l}\text { Diversity and evolution of avian influenza viruses in live poultry } \\
\text { markets, free-range poultry, and wild wetland birds in China }\end{array}$} & 2016 & $2014-2015$ & China & Hubei & Turtledove & Fecal & 245 & 20 & 8.2 & \multirow{5}{*}{ (Chen et al., 2016) } \\
\hline & 2016 & 2014-2015 & China & Hubei & Duck & Fecal & 91 & 3 & 3.3 & \\
\hline & 2016 & 2014-2015 & China & Hubei & Chicken & Fecal & 48 & 5 & 10.4 & \\
\hline & 2016 & $2014-2015$ & China & Zhejiang & Duck & Fecal & 186 & 4 & 2.2 & \\
\hline & 2016 & $2014-2015$ & China & Zhejiang & Chicken & Fecal & 191 & 2 & 1.0 & \\
\hline \multirow{2}{*}{$\begin{array}{l}\text { Emerging Zoonotic Influenza A Virus Detection in Myanmar: } \\
\text { Surveillance Practices and Findings }\end{array}$} & 2017 & 2014-2016 & Myanmar & N/A & Duck & Oropharyngeal & 4138 & 33 & 0.8 & \multirow{2}{*}{ (Tun Win et al., 2017) } \\
\hline & 2017 & 2014-2016 & Myanmar & N/A & Chicken & Oropharyngeal & 2153 & 42 & 2.0 & \\
\hline \multirow{11}{*}{$\begin{array}{l}\text { Diversity, evolution and population dynamics of avian influenza } \\
\text { viruses circulating in the live poultry markets in China }\end{array}$} & 2017 & 2014-2015 & China & Hubei & Duck & Fecal & 118 & 12 & 10.2 & \multirow{11}{*}{ (Chen et al., 2017) } \\
\hline & 2017 & 2014-2015 & China & Hubei & Duck & Cloacal & 134 & 10 & 7.5 & \\
\hline & 2017 & 2014-2015 & China & Hubei & Chicken & Fecal & 145 & 20 & 13.8 & \\
\hline & 2017 & $2014-2015$ & China & Hubei & Chicken & Cloacal & 120 & 6 & 5.0 & \\
\hline & 2017 & 2014-2015 & China & Zhejiang & Duck & Fecal & 91 & 4 & 4.4 & \\
\hline & 2017 & 2014-2015 & China & Zhejiang & Duck & Cloacal & 50 & 0 & 0.0 & \\
\hline & 2017 & 2014-2015 & China & Zhejiang & Chicken & Fecal & 95 & 6 & 6.3 & \\
\hline & 2017 & 2013-2015 & China & Zhejiang & Chicken & Cloacal & 80 & 3 & 3.8 & \\
\hline & 2017 & 2014-2015 & China & Zhejiang & Pigeon & Cloacal & 68 & 1 & 1.5 & \\
\hline & 2017 & 2014-2015 & China & Jiangxi & Duck & Fecal & 132 & 5 & 3.8 & \\
\hline & 2017 & 2014-2015 & China & Jiangxi & Chicken & Fecal & 156 & 2 & 1.3 & \\
\hline \multirow{3}{*}{$\begin{array}{l}\text { Highly pathogenic H5N6 influenza A viruses recovered from wild } \\
\text { birds in Guangdong, southern China, 2014-2015 }\end{array}$} & 2017 & 2014-2015 & China & Guandong & $\mathrm{CM}$ & Fecal & 18 & 1 & 5.6 & \multirow{3}{*}{ (Kang et al., 2017) } \\
\hline & 2017 & 2014-2015 & China & Guandong & PS & Fecal & 42 & 1 & 2.4 & \\
\hline & 2017 & 2014-2015 & China & Guandong & OMR & Fecal & 14 & 1 & 7.1 & \\
\hline $\begin{array}{l}\text { Shifting Clade Distribution, Reassortment, and Emergence of New } \\
\text { Subtypes of Highly Pathogenic Avian Influenza A(H5) Viruses } \\
\text { Collected from Vietnamese poultry from } 2012 \text { to } 2015\end{array}$ & 2016 & $2012-2015$ & Vietnam & Vietnam & Poultry & Oropharyngeal & 194 & 20 & 10.3 & (Nguyen et al., 2017) \\
\hline \multirow{2}{*}{$\begin{array}{l}\text { First Detection of a Novel Reassortant Avian Influenza A(H5N6) } \\
\text { Clade 2.3.2.1c Virus, Isolated from a Wild Bird in China }\end{array}$} & 2019 & 2016 & China & N/A & SD & Fecal & 89 & 7 & 7.9 & \multirow{2}{*}{ (Zhang et al., 2019) } \\
\hline & 2019 & 2016 & China & N/A & YBQ & Fecal & 85 & 6 & 7.1 & \\
\hline $\begin{array}{l}\text { Genetic and antigenic characterization of } \mathrm{H} 5, \mathrm{H} 6 \text {, and } \mathrm{H} 9 \text { avian } \\
\text { influenza viruses circulating in live bird markets with intervention in } \\
\text { the center part of Vietnam }\end{array}$ & 2016 & 2014 & Vietnam & Thua Thien Hue & Duck & Fecal & 175 & 8 & 4.6 & (Chu et al., 2016) \\
\hline
\end{tabular}




\begin{tabular}{|c|c|c|c|c|c|c|c|c|c|c|}
\hline Title of the study & $\begin{array}{l}\text { Publication } \\
\quad \text { Year }\end{array}$ & $\begin{array}{l}\text { Study } \\
\text { Years }\end{array}$ & Country & Place & Birds Assessed & Sample & $\mathbf{N}$ & $\begin{array}{c}\mathbf{n} \\
(+)\end{array}$ & $\begin{array}{l}\text { Positive } \\
(\%)\end{array}$ & Reference \\
\hline $\begin{array}{l}\text { Poultry trading behaviors in Vietnamese live bird markets as risk } \\
\text { factors for avian influenza infection in chickens }\end{array}$ & 2019 & 2017 & Vietnam & northern Vietnam & Chicken & Oropharyngeal & 169 & 16 & 9.5 & (Sealy et al., 2019) \\
\hline $\begin{array}{l}\text { Identification of two novel avian influenzas a (H5N6) viruses in } \\
\text { wild birds, Shanghai, in } 2016\end{array}$ & 2017 & 2016 & China & $\begin{array}{l}\text { Shanghai: Chongming } \\
\text { Dongtan, Nanhui } \\
\text { Dongtan, Jiuduansha }\end{array}$ & Duck & CTS & 127 & 60 & 47.2 & (He et al., 2017) \\
\hline $\begin{array}{l}\text { Genetics, pathogenicity, and transmissibility of novel reassortant } \\
\text { H5N6 highly pathogenic avian influenza viruses first isolated from } \\
\text { migratory birds in western China }\end{array}$ & 2018 & 2015 & China & Changshantou & Duck & OCS & 80 & 17 & 21.3 & (Lu et al., 2018) \\
\hline $\begin{array}{l}\text { First Detection of a Novel Reassortant Avian Influenza A(H5N6) } \\
\text { Clade 2.3.2.1c Virus, Isolated from a Wild Bird in China }\end{array}$ & 2019 & 2016 & China & Suichuan County & Wild bird & TCS & 13 & 7 & 53.8 & (Zhang et al., 2019) \\
\hline $\begin{array}{l}\text { Fatal H5N6 Avian Influenza Virus Infection in a Domestic Cat and } \\
\text { Wild Birds in China }\end{array}$ & 2015 & 2014 & China & Sichuan province & Wild bird & Feces & 70 & 1 & 1.4 & (Yu et al., 2015) \\
\hline $\begin{array}{l}\text { Detection of highly pathogenic avian influenza } \mathrm{A}(\mathrm{H} 5 \mathrm{~N} 6) \text { viruses in } \\
\text { waterfowl in Bangladesh }\end{array}$ & 2019 & $2016-2017$ & Bangladesh & & Poultry & TCS & 2375 & 10 & 0.4 & (Yang et al., 2019) \\
\hline $\begin{array}{l}\text { Novel H7N2 and H5N6 Avian influenza A viruses in sentinel } \\
\text { chickens: A sentinel chicken surveillance study }\end{array}$ & 2016 & 2014 & China & Jiangsu Province & Chicken & CTS & 1623 & 1 & 0.1 & (Zhao et al., 2016) \\
\hline $\begin{array}{l}\text { Novel H5N6 Avian Influenza Virus Reassortants with European } \\
\text { H5N8 Isolated in Migratory Birds, China }\end{array}$ & 2020 & 2017 & China & $\begin{array}{c}\text { Ningxia Hui } \\
\text { Autonomous Region }\end{array}$ & Waterfowl & OCS & 101 & 5 & 5.0 & (Sun et al., 2020) \\
\hline
\end{tabular}

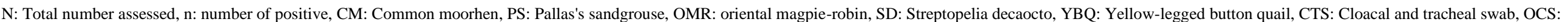
Oropharyngeal and cloacal swabs, TCS: Tracheal and cloacal swab, N/A: Not available or reported. 
Table 2. Meta-analysis outcomes (random-effects model) (prevalences of influenza H5N6, overall and subanalyses)*

\begin{tabular}{|c|c|c|c|c|c|c|c|c|}
\hline Subgroups & $\begin{array}{c}\text { Number of } \\
\text { Studies }\end{array}$ & $\begin{array}{c}\text { Pool } \\
\text { Prevalence }(\%)\end{array}$ & $\begin{array}{c}95 \% \\
\text { CI }\end{array}$ & $\mathbf{n}$ & $\mathbf{Q}^{\dagger}$ & $\mathbf{I}^{2 \ddagger}$ & $\mathrm{t}^{2 \S}$ & p value \\
\hline All the studies & 15 & 3.5 & $2.8-4.3$ & 13,416 & 373.460 & 91.431 & 0.001 & $<0.001$ \\
\hline \multicolumn{9}{|l|}{ Prevalence by Bird grouping } \\
\hline Ducks & 11 & 7.7 & 4.4-11.0 & 5,322 & 126.786 & 93.86 & 0.001 & $<0.001$ \\
\hline Chickens & 10 & 3.3 & $1.9-4.8$ & 4,780 & 101.601 & 91.14 & 0.001 & $<0.001$ \\
\hline Non-specified poultry & 2 & 5.1 & $0.0-14.8$ & 2,569 & 20.439 & 95.11 & 0.001 & $<0.001$ \\
\hline \multicolumn{9}{|l|}{ Prevalence by Countries } \\
\hline Vietnam & 3 & 7.9 & $4.0-11.7$ & 538 & 5.811 & 65.58 & 0.100 & 0.05 \\
\hline China & 28 & 6.0 & $4.3-7.8$ & 4,212 & 298.457 & 90.72 & 0.001 & $<0.001$ \\
\hline Myanmar & 2 & 1.3 & $0.2-2.5$ & 6,291 & 12.320 & 91.88 & 0.001 & $<0.001$ \\
\hline \multicolumn{9}{|l|}{ Prevalence by Years } \\
\hline 2019 & 5 & 8.3 & $1.7-15.0$ & 2,731 & 43.323 & 90.77 & 0.001 & $<0.001$ \\
\hline 2017 & 17 & 4.9 & $3.4-6.5$ & 7,681 & 175.786 & 90.9 & 0.001 & $<0.001$ \\
\hline 2016 & 8 & 4.0 & $1.8-6.2$ & 2,753 & 65.279 & 89.28 & 0.001 & $<0.001$ \\
\hline
\end{tabular}

* 95\% CI: $95 \%$ confidence interval. $\dagger$ Cochran's Q statistic for heterogeneity. $\ddagger \mathrm{I}^{2}$ index for the degree of heterogeneity. $\S$ Tau-squared measure of heterogeneity.

\section{DISCUSSION}

Recent studies suggest that HPAI outbreaks from 2016 to 2018 caused by novel reassortant clade 2.3.4.4 H5N6 viruses resulted in the death of one billion birds in South Korea (Shin et al., 2020). In 2020, the clade 2.3.4.4B was reported in Iran after complete-genome sequencing of $28 \mathrm{H} 5 \mathrm{Nx}$ viruses circulating in the country from 2016 to 2018 (Abdollahi et al., 2020). In the same year, a study reported the first African case of HPAI (H5N6) virus (clade 2.3.4.4b) in a duck identified at a live-poultry market (LPM) in Nigeria whose genome was nearly linked to the European H5N6 viruses (2017-2018) (Shittu et al., 2020). However, as observed in the current meta-analysis, a tremendous prevalence burden exists within the Asian continent.

The prevalence rates of H5N6 infection using RT-PCR were reported up to 7.7\%, with an upper limit of the confidence level of $11.0 \%$ in ducks and $3.3 \%$ in chickens. Both birds (ducks and chickens) share close contact with human beings, especially in the Asian live-poultry market (Fang et al., 2016). Ducks play a critical role in viral preservation and dissemination throughout different settings and environments. Thus, the control of H5N6 within LMPs is pivotal to eradicate influenza from poultry (Chen et al., 2019; de Vries et al., 2018). The continued interaction between humans and poultry in these settings poses a significant risk for human spillover infection and potential emerging health threats of epidemic or pandemic proportions. The increased H5N6 prevalence in LPMs has shifted public health efforts towards sustained LPM surveillance to retrieve relevant epidemiological information and provide early warnings of human infection with AIV. Interventions, such as live-poultry market surveillance and closings, should be implemented to mitigate the potential risk of infection in humans when these viruses are detected widely (Fang et al., 2016).

H5N6 Influenza is just one example of a current systematic phenomenon. The complete focus of public health towards Coronavirus disease 2019 (COVID-19) detracts nearly all attention away from other latent but relevant infectious diseases. As observed in the present meta-analysis, from 2015 to 2020, there has been consistent evidence of approximately 3\% prevalence rates by RT-PCR for H5N6 Influenza in birds.

In 2020, a study reported a patient infected with the avian influenza A (H5N6) virus by aerosol exposure in China (Li et al., 2020). That case had no history of exposure to LMPs but had a record of exposure to live poultry placed in a car with closed doors and windows. The samples collected from the patient's lower respiratory tract and remaining frozen chicken meat were positive for the influenza A (H5N6) virus (Li et al., 2020). Earlier that year, a fatal case of H5N6 in an obese 9-year-old Chinese girl was reported. She was initially presented with fever and coughing, and then pneumonia, Acute Respiratory Distress Syndrome, and respiratory failure were developed. Aspirates from the lower respiratory tract and anal swabs were taken serially in that patient up to the death. A novel reassortant H5N6 virus was isolated, and genome sequencing and phylogenetic analysis were performed. Except for the polymerase acid protein (PA) gene, all the other seven genes of the virus belonged to H5N6 genotype A (S4-like virus) (Chen et al., 2020). Given these alarming cases in China, extraordinary measures should be implemented to mitigate or avoid future outbreaks of avian influenza. 
Although the current meta-analysis found a pool prevalence of 3.5\%, some selected studies reached more than $21 \%$ (Figure 3). Considering the number of assessed birds, these findings should be considered relevant. A significant concern is raised, even more considering that there are no effective vaccines to prevent human H5N6 Influenza infection, although some candidates have been recently tested (Chen et al., 2019; de Vries et al., 2018). One of them, the rDEVus78HA vaccine, efficiently protected ducks against challenges with isolated heterologous H5N6 and H5N8 viruses (Chen et al., 2019). Another vaccine candidate, rMVA-H5 (Clinical trials registration: NTR3401), seemed to be effective against antigenically distinct $\mathrm{H} 5$ viruses (de Vries et al., 2018).

Primary prevention is critical in diseases with a high case fatality rate, typical for many HPAI infection cases (Bi et al., 2016). H5N6 virus induces large economic losses to poultry breeding industries in developing regions worldwide, especially in Asia. HPAI H5 clade 2.3.4.4 viruses were introduced in Europe in late 2014 and re-introduced in late 2016, following detections in Asia and Russia (Poen et al., 2019). Recent outbreaks reported in captive Pavo cristatus in Jiangxi Province, China, suggest avian influenza as a critical latent threat to public health (Li et al., 2019).

The present results highlighted the relevance of individual birds as reservoirs for H5N6. Ducks and chickens were found positive by RT-PCR in over 3\% of the cases, showcasing their relevance in maintaining zoonotic transmission with the consequent risk of disease outbreaks. Additional research and enhanced LPM in China and other countries worldwide should be promptly considered to prevent more subsequent outbreaks.

\section{DECLARATIONS}

Present study was a part of the thesis of Veterinary Medicine and Zootechnics of D.C. Erazo-Arana, at Universidad Tecnológica de Pereira, Pereira, Risaralda, Colombia, under the supervision of D.K. Bonilla-Aldana and A.J. RodriguezMorales.

\section{Authors' contributions}

D. Katterine Bonilla-Aldana conceived the idea of the study. Yeimer Holguin-Rivera, Isabella Cortes-Bonilla, María C. Cardona-Trujillo, Alejandra García-Barco, Hugo A. Bedoya-Arias, Leidy Jhoana Patiño-Cadavid, Mateo Aguirre-Florez, Graciela J. Balbin-Ramon, Delcy C. Erazo-Arana collected data. Alfonso J. Rodriguez-Morales and D. Katterine Bonilla-Aldana analyzed the data. Alfonso J. Rodriguez-Morales wrote the first draft. All authors wrote and revised the subsequent drafts. All authors approved the final submitted version and the data analysis.

\section{Funding}

The current study was funded by the Dirección de Investigación Científica, Humanística y Tecnológica (2-05-0101), National Autonomous University of Honduras, Tegucigalpa, MDC, Honduras, Central America.

\section{Competing interests}

All authors declare no competing interests to be reported.

\section{REFERENCES}

Abdollahi H, Ali ASM, Monne I, Milani A, Habibi M, Zamperin G, Ghafouri SA, Maghsoudloo H, Mohammadpoor B, Esmaeilzadeh S et al. (2020). Spatial spread and emergence of reassortant h5 highly pathogenic avian influenza viruses in Iran reassortant h5 highly pathogenic avian influenza virus in Iran. Infection Genetics and Evolution, 83: Article number 104342. DOI: https://www.doi.org/10.1016/j.meegid.2020.104342

Bi Y, Chen Q, Wang Q, Chen J, Jin T, Wong G, Quan C, Liu J, Wu J, Yin R et al. (2016). Genesis, evolution and prevalence of h5n6 avian influenza viruses in China. Cell Host and Microbe, 20(6): 810-821. DOI: https://www.doi.org/10.1016/j.chom.2016.10.022

Chen LJ, Lin XD, Guo WP, Tian JH, Wang W, Ying XH, Wang MR, Yu B, Yang ZQ, Shi M et al. (2016). Diversity and evolution of avian influenza viruses in live poultry markets, free-range poultry and wild wetland birds in China. Journal of General Virology, 97(4): 844-854. DOI: https://www.doi.org/10.1099/jgv.0.000399

Chen LJ, Lin XD, Tian JH, Liao Y, Ying XH, Shao JW, Yu B, Guo JJ, Wang MR, Peng Y et al. (2017). Diversity, evolution and population dynamics of avian influenza viruses circulating in the live poultry markets in China. Virology, 505: 33-41. DOI: https://www.doi.org/10.1016/j.virol.2017.02.009

Chen LL, Huo X, Qi X, Liu C, Huang H, Yu H, Dong Z, Deng F, Peng J, Hang H et al. (2020). A fatal paediatric case infected with reassortant avian influenza a(h5n6) virus in eastern China. Transboundary and Emerging Diseases, In press. DOI: https://www.doi.org/10.1111/tbed.13561

Chen P, Ding L, Jiang Y, Zeng X, Deng G, Shi J, Li Y, Liu L, Zhao Y, Hu Y et al. (2019). Protective efficacy in farmed ducks of a duck enteritis virusvectored vaccine against h5n1, h5n6, and h5n8 avian influenza viruses. Vaccine, 37(40): 5925-5929. DOI: https://www.doi.org/10.1016/j.vaccine.2019.08.026

Chu DH, Okamatsu M, Matsuno K, Hiono T, Ogasawara K, Nguyen LT, Van Nguyen L, Nguyen TN, Nguyen TT, Van Pham D et al. (2016). Genetic and antigenic characterization of h5, h6 and h9 avian influenza viruses circulating in live bird markets with intervention in the center part of Vietnam. Veterinary Microbiology, 192: 194-203. DOI: https://www.doi.org/10.1016/j.vetmic.2016.07.016

de Vries RD, Altenburg AF, Nieuwkoop NJ, de Bruin E, van Trierum SE, Pronk MR, Lamers MM, Richard M, Nieuwenhuijse DF, Koopmans MPG et al. (2018). Induction of cross-clade antibody and t-cell responses by a modified vaccinia virus Ankara-based influenza a(h5n1) vaccine in a randomized phase 1/2a clinical trial. The Journal of Infectious Diseases, 218(4): 614-623. DOI: https://www.doi.org/10.1093/infdis/jiy214

Dhingra MS, Artois J, Dellicour S, Lemey P, Dauphin G, Von Dobschuetz S, Van Boeckel TP, Castellan DM, Morzaria S, and Gilbert M (2018). Geographical and historical patterns in the emergences of novel highly pathogenic avian influenza (hpai) h5 and h7 viruses in poultry. Frontiers in Veterinary Science, 5: Article number 84. DOI: https://www.doi.org/10.3389/fvets.2018.00084 
Downes MJ, Brennan ML, Williams HC, and Dean RS (2016). Development of a critical appraisal tool to assess the quality of cross-sectional studies (axis). BMJ Open, 6(12): e011458. DOI: https://www.doi.org/10.1136/bmjopen-2016-011458

Fang S, Bai T, Yang L, Wang X, Peng B, Liu H, Geng Y, Zhang R, Ma H, Zhu W et al. (2016). Sustained live poultry market surveillance contributes to early warnings for human infection with avian influenza viruses. Emerging Microbes and Infections, 5(8): e79. DOI: https://www.doi.org/10.1038/emi.2016.75

Garcia M, Suarez DL, Crawford JM, Latimer JW, Slemons RD, Swayne DE, and Perdue ML (1997). Evolution of h5 subtype avian influenza a viruses in North America. Virus Research, 51(2): 115-124. DOI: https://www.doi.org/10.1016/s0168-1702(97)00087-7

He G, Zhou L, Zhu C, Shi H, Li X, Wu D, Liu J, Lv J, Hu C, Li Z et al. (2017). Identification of two novel avian influenza a(h5n6) viruses in wild birds, shanghai, in 2016. Veterinary Microbiology, 208: 53-57. DOI: https://www.doi.org/10.1016/j.vetmic.2017.07.017

Institute of Health Economics (IHE) (2014). Quality appraisal of case series studies checklist. Available at: http://www.ihe.ca/researchprograms/rmd/cssqac/cssqac-about

Kang Y, Liu L, Feng M, Yuan R, Huang C, Tan Y, Gao P, Xiang D, Zhao X, Li Y et al. (2017). Highly pathogenic h5n6 influenza a viruses recovered from wild birds in Guangdong, southern China, 2014-2015. Scientific Reports, 7: Article number $44410 . \quad$ DOI: https://www.doi.org/10.1038/srep44410

Lefkowitz EJ, Dempsey DM, Hendrickson RC, Orton RJ, Siddell SG, and Smith DB (2018). Virus taxonomy: The database of the international committee on taxonomy of viruses (ictv). Nucleic Acids Research, 46: 708-717. DOI: https://www.doi.org/10.1093/nar/gkx932

Li G, Fan Y, Lai Y, Han T, Li Z, Zhou P, Pan P, Wang W, Hu D, Liu X et al. (2020). Coronavirus infections and immune responses. Journal of Medical Virology, 92(4): 424-432. DOI: https://www.doi.org/10.1002/jmv.25685

Li M, Feng S, Lv S, Luo J, Guo J, Sun J, and He H (2019). Highly pathogenic h5n6 avian influenza virus outbreak in Pavo cristatus in Jiangxi province, China. Emerging Microbes and Infections, 8(1): 377-380. DOI: https://www.doi.org/10.1080/22221751.2019.1586411

Lu S, Zhao Z, Zhang J, Wang W, He X, Yu M, Zhang C, Li X, Guo Z, Yang X et al. (2018). Genetics, pathogenicity and transmissibility of novel reassortant h5n6 highly pathogenic avian influenza viruses first isolated from migratory birds in western China. Emerging Microbes and Infections, 7(1): Article number 6. DOI: https://www.doi.org/10.1038/s41426-017-0001-1

Moher D, Liberati A, Tetzlaff J, Altman DG, and Group P (2009). Preferred reporting items for systematic reviews and meta-analyses: The Prisma statement. PLOS Medicine, 6(7): e1000097. DOI: https://www.doi.org/10.1371/journal.pmed.1000097

Nguyen DT, Jang Y, Nguyen TD, Jones J, Shepard SS, Yang H, Gerloff N, Fabrizio T, Nguyen LV, Inui K et al. (2017). Shifting clade distribution, reassortment, and emergence of new subtypes of highly pathogenic avian influenza a(h5) viruses collected from Vietnamese poultry from 2012 to 2015. Journal of Virology, 91(5): 1-18. DOI: https://www.doi.org/10.1128/JVI.01708-16

Pan M, Gao R, Lv Q, Huang S, Zhou Z, Yang L, Li X, Zhao X, Zou X, Tong W et al. (2016). Human infection with a novel, highly pathogenic avian influenza $\mathrm{a}(\mathrm{h} 5 \mathrm{n} 6)$ virus: Virological and clinical findings. Journal of Infection, $72(1)$ : 52-59. DOI: https://www.doi.org/10.1016/j.jinf.2015.06.009

Poen MJ, Venkatesh D, Bestebroer TM, Vuong O, Scheuer RD, Oude Munnink BB, de Meulder D, Richard M, Kuiken T, Koopmans MPG et al. (2019). Co-circulation of genetically distinct highly pathogenic avian influenza a clade 2.3.4.4 (h5n6) viruses in wild waterfowl and poultry in Europe and East Asia, 2017-18. Virus Evolution, 5(1): Artice number 4. DOI: https://www.doi.org/10.1093/ve/vez004

Rodriguez-Morales AJ, Cardona-Ospina JA, Gutierrez-Ocampo E, Villamizar-Pena R, Holguin-Rivera Y, Escalera-Antezana JP, Alvarado-Arnez LE, Bonilla-Aldana DK, Franco-Paredes C, Henao-Martinez AF et al. (2020). Clinical, laboratory and imaging features of covid-19: A systematic review and meta-analysis. Travel Medicine and Infectious Disease, 34: Article number 101623. DOI: https://www.doi.org/10.1016/j.tmaid.2020.101623

Sealy JE, Fournie G, Trang PH, Dang NH, Sadeyen JR, Thanh TL, van Doorn HR, Bryant JE, and Iqbal M (2019). Poultry trading behaviours in Vietnamese live bird markets as risk factors for avian influenza infection in chickens. Transboundary and Emerging Diseases, 66(6): 2507-2516. DOI: https://www.doi.org/10.1111/tbed.13308

Shen H, Wu B, Chen Y, Bi Y, and Xie Q (2015). Influenza a(h5n6) virus reassortant, southern China, 2014. Emerging Infectious Diseases, 21(7): 1261-1262. DOI: https://www.doi.org/10.3201/eid2107.140838

Shin J, Kang S, Byeon H, Cho SM, Kim SY, Chung YJ, and Jung SH (2020). Highly pathogenic h5n6 avian influenza virus subtype clade 2.3.4.4 indigenous in South Korea. Scientific Reports, 10(1): Article number 7241. DOI: https://www.doi.org/10.1038/s41598-020-64125-x

Shittu I, Bianco A, Gado D, Mkpuma N, Sulaiman L, Laleye A, Gobbo F, Bortolami A, Bonfante F, Vakuru C et al. (2020). First detection of highly pathogenic h5n6 avian influenza virus on the African continent. Emerging Microbes and Infections, pp. 1-14. DOI: https://www.doi.org/10.1080/22221751.2020.1757999

Sun J, Zhao L, Li X, Meng W, Chu D, Yang X, Peng P, Zhi M, Qin S, Fu T et al. (2020). Novel h5n6 avian influenza virus reassortants with European h5n8 isolated in migratory birds, China. Transboundary and Emerging Diseases, 67(2): 648-660. DOI: https://www.doi.org/10.1111/tbed.13380

Swayne DE, Hill RE, and Clifford J (2017). Safe application of regionalization for trade in poultry and poultry products during highly pathogenic avian influenza outbreaks in the USA. Avian Pathology, 46(2): 125-130. DOI: https://www.doi.org/10.1080/03079457.2016.1257775

Tun Win Y, Gardner E, Hadrill D, Su Mon CC, Kyin MM, Maw MT, Claes F, von Dobschuetz S, Kalpravidh W, Wongsathapornchai K et al. (2017). Emerging zoonotic influenza a virus detection in myanmar: Surveillance practices and findings. Health Security, 15(5): 483-493. DOI: https://www.doi.org/10.1089/hs.2016.0131

Wong FY, Phommachanh P, Kalpravidh W, Chanthavisouk C, Gilbert J, Bingham J, Davies KR, Cooke J, Eagles D, Phiphakhavong S et al. (2015). Reassortant highly pathogenic influenza a(h5n6) virus in Laos. Emerging Infectious Diseases, 21(3): 511-516. DOI: https://www.doi.org/10.3201/eid2103.141488

World Health Organization (WHO) (2020). Human infection with avian influenza a(h5) viruses. Human infection with avian influenza A(H5N6) virus Retrieved 03/23/2020, 2020. Available at: https://www.who.int/docs/default-source/wpro---documents/emergency/surveillance/avianinfluenza/ai-20200313.pdf?sfvrsn=223ca73f_42

Yang G, Chowdury S, Hodges E, Rahman MZ, Jang Y, Hossain ME, Jones J, Stark TJ, Di H, Cook PW et al. (2019). Detection of highly pathogenic avian influenza a(h5n6) viruses in waterfowl in Bangladesh. Virology, 534: 36-44. DOI: https://www.doi.org/10.1016/j.virol.2019.05.011

Yu Z, Gao X, Wang T, Li Y, Li Y, Xu Y, Chu D, Sun H, Wu C, Li S et al. (2015). Fatal h5n6 avian influenza virus infection in a domestic cat and wild birds in China. Scientific Reports, 5: Article number 10704. DOI: https://www.doi.org/10.1038/srep10704

Zhang T, Li R, Zhu G, Chang J, and Xu B (2019). First detection of a novel reassortant avian influenza a(h5n6) clade 2.3.2.1c virus, isolated from a wild bird in china. Microbiology Resource Announcements, 8(36): e00797-19. DOI: https://www.doi.org/10.1128/MRA.00797-19

Zhao T, Qian YH, Chen SH, Wang GL, Wu MN, Huang Y, Ma GY, Fang LQ, Gray GC, Lu B et al. (2016). Novel h7n2 and h5n6 avian influenza a viruses in sentinel chickens: A sentinel chicken surveillance study. Frontiers in Microbiology, 7: Article number 1766. DOI: https://www.doi.org/10.3389/fmicb.2016.01766 